\title{
Rare-earth Elements in Apatite from Layered Norites and Iron-Titanium Oxide Ore-bodies Related to Anorthosites (Rogaland, S.W. Norway)
}

\author{
IWAN ROELANDTS and JEAN-CLAIR DUCHESNE
}

Géologie-Pétrologie-Géochimie, Université de Liège, Sart Tilman, Belgium

\begin{abstract}
Rare-earth elements (REE) were investigated by neutron-activation analysis in nine apatites and seven coexisting plagioclase cumulate minerals at three different levels of the Bjerkrem-Sogndal layered lopolith (Rogaland, S.W. Norway), a massif which displays the complete andesine anorthosite-charnockite series of rocks.

The REE (except Eu) behave as hygromagmatophile elements (as defined by Treuil) in the course of the fractional crystallization process which has given rise to the massif. The concentration is indeed inversely proportional to $F$, the fraction of residual liquid. This characteristic permits placing an upper limit to the value of the partition coefficients of REE between apatite and magma. They must approximately be equal or less than 5 . The apatite-plagioclase distribution coefficients show little variation during differentiation. This can be explained by an open system crystallization of the intercumulus liquid and permits calculating the plagioclasemagma partition coefficients. Values similar to those of Paster et al. (1974) are obtained.
\end{abstract}

A range of possible $\mathrm{D}_{\mathrm{Eu}}^{\text {apat }}$ is calculated, together with the corresponding $\mathrm{D}_{\mathrm{Eu}}^{\mathrm{plag}}$ at three different levels of the intrusion. Drake's (1975) geobarometer based on Eu in plagioclase is used to estimate the fugacity of oxygen. There is good agreement with the values obtained with the Buddington and Lindsley geobarometer. A continuous decrease of $f_{\mathrm{O} 2}$ throughout the whole sequence cannot be invalidated.

REE were also determined in apatite from five Fe-Ti oxide ore-bodies occurring in the same magmatic province. The consistency between the trace element behaviour in the oxides and the REE in the apatite permits identifying fractional crystallization as controlling the generation of the ore-bodies.

\section{Introduction}

Quantitative modelling of trace element behaviour in magmatic processes constitutes one of the most powerful methodological tools geochemistry has supplied to petrology. However, the method, to be fully efficient, requires knowledge of partition coefficients of trace elements between minerals and magma.

Direct measurement of partition coefficients of traces between phenocrysts and matrix in experimental systems or in natural rocks is the generally recommended method of determination. However, it has been suggested (Duchesne, 1971 ; Paster et al, 1974) to treat this question by studying minerals in magmatic cumulate series of layered intrusions. Indeed, the very slow cooling of these intrusions and the amount of monomineralic cumulates suggest that ideal conditions of equilibrium and complete separation of the liquid from the solid are approached.

The present paper describes an application of this method to apatite, a mineral commonly accessory in rocks but rich in trace elements such as the REE. The data obtained by Nagasawa (1970) for REE partition coefficients for apatite in dacites show very high values (as much as 100). Several authors have pointed out the possible - and so far neglected - role of this mineral in balancing the effect of crystallization of silicate minerals (e.g. Zielinski and Frey, 1970). Others have questioned the high values : Paster et al. (1974) have calculated that values of 8 to 16 lead, in the Skaergaard intrusion, to the model most consistent with the petrological data; Sun and Hanson (1976) inferred values of about 5 or less on the basis of apatite-clinopyroxene partition coefficients.

Our purpose is to show that low values (5-10) for REE partition coefficients in apatite can be deduced from the study of a layered intrusion, namely the Bjerkrem-Sogndal lopolith. These results will also be applied to some 
apatite-rich, Fe-Ti oxide ore-bodies.

The first author (I.R.) is mainly responsible for the analytical work, the second (J. C. D.) has collected the samples and led the petrological and geochemical study.

\section{Experimental}

Mineral fractions were purified by means of heavy liquids and a magnetic separator. Extreme caution was exercised in the separation of plagioclase to avoid contamination by apatite. Heavy liquid density was adjusted as close as possible to that of the plagioclase to be separated and the fractions were leached with hot $4 \mathrm{NHCl}$.

The neutron-activation procedures were performed at the Mineralogical Geological Museum, University of Oslo, Norway.

For apatite, REE were determined non-destructively by $\mathrm{Ge}(\mathrm{Li}) \gamma$-spectrometry with thermal (La, $\mathrm{Ce}, \mathrm{Nd}, \mathrm{Eu}, \mathrm{Tb}$, $\mathrm{Dy}, \mathrm{Yb}$ and $\mathrm{Lu})$ and epithermal ( $\mathrm{Sm}, \mathrm{Gd}, \mathrm{Ho}, \mathrm{Er})$ reactor neutrons on two independent fractions of the mineral; a known amount of each REE was used as monitor samples (Brunfelt and Roelandts, 1974). The precision $\left(\mathrm{t}_{0,95} \mathrm{~s}\right)$ estimated from replicate measurements was better than $5 \%$ for $\mathrm{La}, \mathrm{Sm}, \mathrm{Eu}, \mathrm{Dy}, 10-15 \%$ for $\mathrm{Ce}, \mathrm{Tb}, \mathrm{Yb}$ and about $20 \%$ for $\mathrm{Nd}, \mathrm{Gd}, \mathrm{Ho}, \mathrm{Er}$ and $\mathrm{Lu}$, within the range of concentrations studied here.

As for plagioclase, due to the extremely low concentrations of REE ( $p p b$ to ppm range), a radiochemical group separation was carried out after a 7-day thermal neutron activation. An oxidant alkaline fusion of the irradiated sample was followed by leaching with water. The insoluble hydroxide fraction was dissolved in $\mathrm{HC} 1$ and analysed for eight REE by $y$-spectrometry (Roelandts, 1975). The USGS reference sample BCR-1 was used as the standard. The working conditions were chosen to give approximately the same precision as that obtained for apatite, i.e. $15-20 \%$ for $\mathrm{Nd}, \mathrm{Tb}, \mathrm{Yb}$ and $\mathrm{Lu}$, and about 5-10\% for the other measured REE. Single instrumental NAA was also used for analysing two plagioclase samples (7969 and 6675: see Table 1) with less precision and higher detection limit.

\section{The Bjerkrem-Sogndal Lopolith}

The Bjerkrem-Sogndal (Bk-Sg) massif situated in the anorthositic province of Egersund (Rogaland, S.W. Norway) is a synkinematic layered lopolith (Michot, 1960, 1965). It displays the complete anorthositecharnockite series of rocks and results from a gravity differentiation process. Micro- and macrotextures typical of igneous layered cumulates (Wager and Brown, 1968) characterize the rocks (lamination, small-scale rhythmic layering, banding, etc.). The lower part of the massif is essentially formed by anorthosites, leuconorites and norites. It has been divided into five macroscale rhythmic units (I to V) (Michot, 1960) which are anorthositic or leuconoritic at the base and grade upward into more mafic terms. They have been interpreted by Duchesne (1972a) as the result of repeated influxes of fresh magma into the magmatic chamber during the crystallization process.

The evolution of the mineralogy (Michot, 1965; Duchesne, 1972a, b) is as follows. Plagioclase $\left(\mathrm{An}_{50-45}\right.$, unzoned), orthopyroxene and hemo-ilmenite, in the average weight proportion of $74 \%, 16 \%$ and $10 \%$, respectively (Duchesne, 1978), characterize the anorthosites and leuconorites of rhythms I, II, bases of III and of IV. Magnetite and apatite together with clinopyroxene first appear in the middle and upper part respectively of III. The same association occurs in the norites of IV and V and grades into jotunitic cumulates, which constitute the rapid transition towards acidic rocks. Apatite-bearing norites show an average weight proportion of $45 \%$ plagioclase $+22 \%$ orthopyroxene $+9 \%$ clinopyroxene $+4 \%$ apatite $+20 \%$ oxides (Duchesne, 1978). The An content of plagioclase decreases regularly from III to $\mathrm{V}$. Though plagioclase is always granulated and this phenomenon often blurs the typical texture of cumulates, the plagioclase has originally accumulated as primocrysts. In rhythms III and IV, pyroxenes form euhedral primocrysts, but in V, orthopyroxene (inverted pigeonite) shows a poikilitic structure. The oxides always fill the interstices between the silicate minerals. Coarse apatite crystals lie parallel to the general lamination. Smaller ones may also be included in the oxides or in the poikilitic pyroxenes. 
Published in : Origin and distribution of the elements (1979), pp. 199-212 Status : Postprint (Author's version)

Table 1.. REE Contents (ppm) in APATIte and Plagioclase

\begin{tabular}{|c|c|c|c|c|c|c|c|c|c|c|c|c|c|c|c|c|}
\hline \multicolumn{17}{|c|}{ Bjerkrem-Sogndal lopolith } \\
\hline & \multicolumn{8}{|c|}{ Rhythm III } & \multicolumn{8}{|c|}{ Rhythm IV } \\
\hline & \multicolumn{2}{|c|}{ JCD6674 } & \multicolumn{2}{|c|}{7969} & \multirow{2}{*}{$\begin{array}{l}7970 \\
\text { Apat }\end{array}$} & \multirow{2}{*}{$\begin{array}{l}\text { JCD6675 } \\
\text { Plag }\end{array}$} & \multicolumn{2}{|c|}{ Average } & \multicolumn{2}{|c|}{ JCD6444 } & \multicolumn{2}{|c|}{ JCD6695 } & \multicolumn{2}{|c|}{$\begin{array}{c}\text { JCD6621 } \\
2 \\
\end{array}$} & \multicolumn{2}{|c|}{ Average } \\
\hline & Apat & Plag & Apat & lag & & & Apat & Plag & Apat & Plag & Apat & Plag & Apat & & Apat & Plag \\
\hline $\mathrm{La}$ & 144 & 2.13 & 149 & 1.93 & 162 & 1.84 & 152 & 1.97 & 216 & 2.98 & 248 & 3.19 & 234 & & 233 & 3.09 \\
\hline $\mathrm{Ce}$ & 429 & 3.25 & 414 & 3.27 & 451 & 3.66 & 431 & 3.39 & 606 & 4.94 & 686 & 5.30 & 637 & & 643 & 5.12 \\
\hline $\mathrm{Nd}$ & 532 & 1.3 & 494 & & 485 & & 504 & 1.3 & 479 & 2.1 & 703 & 2.5 & 660 & & 614 & 2.3 \\
\hline Sm & 96.5 & .19 & 95.6 & 16 & 98.7 & .16 & 96.9 & .17 & 130 & .33 & 146 & .29 & 127 & & 134 & .31 \\
\hline $\mathrm{Eu}$ & 20.2 & 1.19 & 19.4 & 1.29 & 21.1 & 1.48 & 20.2 & 1.32 & 25.9 & 1.66 & 26.4 & 2.05 & 26.7 & & 26.3 & 1.86 \\
\hline $\mathrm{Gd}$ & 86.0 & & 85.3 & & 84.5 & & 85.3 & & 125 & & 124 & & 162 & & 137 & \\
\hline $\mathrm{Tb}$ & 13.5 & .015 & 11.5 & $<.02$ & 12.8 & .016 & 12.6 & .016 & 16.1 & .034 & 19.2 & .020 & 16.3 & & 17.2 & .027 \\
\hline Dy & 51.4 & & 53.1 & & 51.9 & & 52.1 & & 65.3 & & 78.4 & & 67.9 & & 70.5 & \\
\hline Ho & 12.2 & & 9.2 & & 9.3 & & 10.2 & & 10.3 & & 14.7 & & 15.2 & & 13.4 & \\
\hline Er & 22.2 & & 19.8 & & 21.5 & & 21.2 & & 26.0 & & 33.8 & & 36.4 & & 32.1 & \\
\hline $\mathrm{Yb}$ & 10.0 & .020 & 9.9 & .1 & 13.5 & $<.1$ & 11.1 & .02 & 17.8 & .043 & 17.4 & .036 & 20.7 & & 18.6 & .039 \\
\hline $\mathrm{Lu}$ & 1.0 & $<.004$ & 1.0 & .006 & 1.2 & $<.006$ & 1.1 & & 1.9 & .007 & 2.1 & .006 & 1.8 & & 1.9 & .006 \\
\hline $\mathrm{La} / \mathrm{Yb}$ & & & & & & & 14 & 99 & & & & & & & 13 & 79 \\
\hline $\mathrm{Eu} / \mathrm{Eu}^{*}$ & & & & & & & 0.68 & 28 & & & & & & & 0.61 & 22 \\
\hline \multirow[t]{5}{*}{ An $\%$} & & 44 & 4 & 12 & & 45 & & 44 & & 44 & & 41 & & & & 43 \\
\hline & \multicolumn{7}{|c|}{ Bjerkrem-Sogndal lopolith } & \multicolumn{9}{|c|}{ Fe-Ti oxide ore bodies } \\
\hline & \multicolumn{7}{|c|}{ Rhythm V } & & Kydl. & Rödem. & \multirow{2}{*}{$\begin{array}{c}\text { Kaknud } \\
.6611\end{array}$} & \multirow{2}{*}{\multicolumn{2}{|c|}{$\begin{array}{c}\text { Eigeröy } \\
66150\end{array}$}} & \multirow{2}{*}{\multicolumn{2}{|c|}{$\begin{array}{l}\text { Hesne } \\
\text { s } 6633\end{array}$}} & \\
\hline & \multicolumn{2}{|c|}{ JCD6460 } & $\begin{array}{c}\text { JCD6610 } \\
3\end{array}$ & \multicolumn{2}{|c|}{$\begin{array}{c}\text { JCD645 } \\
8 \\
\end{array}$} & $\begin{array}{c}\text { JCD66102 } \\
\mathrm{N}\end{array}$ & Average & & 66181 & II 6615 & & & & & & \\
\hline & Apat & Plag & Apat & & pat & Plag & Apat & Plag & Apat & Apat & Apat & & pat & Apat & & hondrite \\
\hline $\mathrm{La}$ & 344 & 4.03 & 337 & 381 & & 3.68 & 354 & 3.86 & 204 & 269 & 286 & 820 & & 951 & 0.3 & \\
\hline $\mathrm{Ce}$ & 947 & 6.24 & 918 & 972 & & 6.07 & 946 & 6.16 & 519 & 729 & 779 & 219 & & 2649 & 0.8 & \\
\hline $\mathrm{Nd}$ & 652 & 2.6 & 658 & 816 & & 2.3 & 709 & 2.45 & $(732)$ & 609 & 626 & 156 & & 2108 & 0.6 & \\
\hline $\mathrm{Sm}$ & 180 & .33 & 175 & 190 & & .31 & 182 & .32 & 136 & 158 & 165 & 421 & & 466 & 0.1 & \\
\hline $\mathrm{Eu}$ & 31.4 & 3.51 & 32.6 & 34.6 & & 3.59 & 32.9 & 3.55 & 30.8 & 30.5 & 32.3 & 43.7 & & 44.5 & 0.0 & \\
\hline Gd & 144 & & 173 & 183 & & & 167 & & 120 & 168 & 175 & 400 & & 423 & 0.2 & \\
\hline $\mathrm{Tb}$ & 26.7 & .015 & 23.7 & 25.1 & & .023 & 25.2 & .019 & 17.7 & 22.8 & 24.3 & 64. & & 67.9 & 0.0 & \\
\hline Dy & 99.8 & & 94.3 & 102 & & & 98.7 & & 87.0 & 92.8 & 99.3 & 273 & & 300 & 0.2 & \\
\hline Но & 14.8 & & 21.9 & 19.4 & & & 18.7 & & 18.3 & 18.1 & 24.9 & 55.2 & & 55.1 & 0.0 & \\
\hline Er & 49.3 & & 43.2 & 36.1 & & & 42.9 & & 32.3 & 33.8 & 43.5 & 131 & & 142 & 0.2 & \\
\hline $\mathrm{Yb}$ & 25.0 & .041 & 23.7 & 23.7 & & .034 & 24.1 & .038 & 19.5 & 24.7 & 24.1 & 73.8 & & 83.9 & 0.2 & \\
\hline $\mathrm{Lu}$ & 2.4 & .004 & 2.1 & 2.3 & & & 2.3 & .004 & 2.7 & 2.1 & 2.1 & 9.0 & & 10.4 & 0.0 & \\
\hline $\mathrm{La} / \mathrm{Yb}$ & & & & & & & 15 & 102 & 10.5 & 10.9 & 11.9 & 11. & & 11.3 & & \\
\hline $\mathrm{Eu} / \mathrm{Eu}^{*}$ & & & & & & & .59 & 43. & 0.72 & 0.57 & 0.58 & 0.32 & & 0.30 & & \\
\hline
\end{tabular}


FIG. 1. Chondrite-normalized REE patterns in average apatites and plagioclases coexisting at three different levels of the Bjerkrem-Sogndal massif. Parental liquid $(O)$ and successive residual magmatic liquids (III, IV, V) calculated. by quantitive modelling using REE* partition coeficients of Table 3 and $\mathrm{D}_{\mathrm{Eu}}^{\text {apat }}=5.8$.

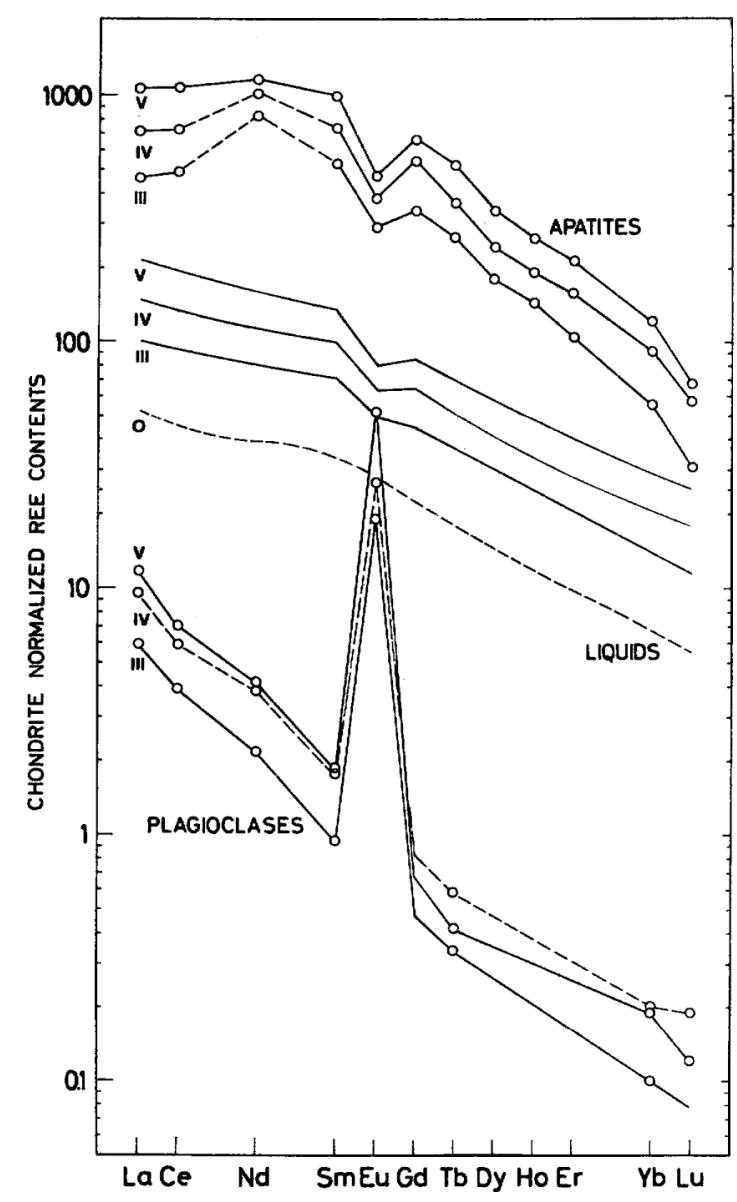

\section{REE in Apatite and Plagioclase}

The results obtained are listed in Table 1. It should be observed that different apatites and different plagioclases from any one rhythm are remarkably similar. We can therefore neglect the internal variations in each rhythm and consider only the average values per rhythm. The chondrite-normalized values are plotted in Fig. 1. For apatite and plagioclase, points are situated on smooth curves, except for Eu which shows a distinct negative anomaly in apatite and a high positive anomaly in plagioclase.

The following remarks can be made:

1. For apatite, parallel curves are obtained (leading to very constant $\mathrm{La} / \mathrm{Yb}$ ratios) except for Eu whose anomaly increases with the concentration and for $\mathrm{Nd}$ which deviates the more from a mean curve the lower its content. A systematic analytical error is suspected for this last element. ${ }^{1}$ This does not allow the rigorous definition of a normal distribution pattern of the light REE (LREE) in the $\mathrm{Nd}$ region and makes impossible the assessment of a possible Ce negative anomaly, as suggested by Puchelt and Emmerman (1976). In any case, the factors which are responsible for the Ce depletion according to these authors cannot have operated here. Ce-rich minerals, such as monazite and allanite, are absent and the evolution of the rocks is characterized by low and decreasing oxygen fugacity (see below) with no indication of a previous stage of evolution in oxidizing conditions. In the following,

\footnotetext{
${ }^{1}$ Counting rates for the ${ }^{147} \mathrm{Nd}$ photopeak at $531.0 \mathrm{keV}$ are low; as for the more sensitive $91.1 \mathrm{keV}$ line of ${ }^{147} \mathrm{Nd}$, it shows an important background, whose subtraction from the peak area can introduce a systematic error, the more important as the $\mathrm{Nd}$ contents are lower
} 
we shall not take into account the $\mathrm{Nd}$ content in apatite.

2. REE* ${ }^{2}$ contents in apatite show a progressive enrichment from rhythm III to rhythm $\mathrm{V}$, concomitant with the differentiation process. Between the two rhythms, the REE* average enrichment factor is $2.0+/-0.2$. The Eu anomaly defined as the $\mathrm{Eu} / \mathrm{Eu}^{*}$ ratio $\left(\mathrm{Eu}^{*}\right.$ being obtained by linear interpolation between Sm and $\left.\mathrm{Gd}\right)$ slightly decreases.

3. For plagioclase, the parallelism of the curves is also striking for the LREE. The La-Sm average enrichment factor between rhythms III and V is $1.9 \pm 0.1$, i.e. close to that observed for apatite. The heavy REE (HREE) pattern for plagioclase is not as well defined as it is for apatite; three elements only ( $\mathrm{Tb}, \mathrm{Yb}$ and $\mathrm{Lu})$ have been measured, the contents are close to the detection limit and the precision of the determination is rather poor. The fact that the plagioclases from rhythm IV have $\mathrm{Tb}, \mathrm{Yb}$ and $\mathrm{Lu}$ contents which are higher than those of plagioclase from rhythm V may be attributed to these factors. Consequently we shall not draw any geochemical conclusion from the behaviour of these three elements in plagioclase. It can, however, be noted that from rhythm III upwards the contents in these elements increase and the $\mathrm{La} / \mathrm{Yb}$ ratio, i.e. the slope of the distribution pattern, remains approximately constant. We thus feel allowed to extrapolate the conclusions drawn from the LREE to the whole REE* in plagioclase. As for Eu in plagioclase, the content and the amplitude of the positive anomaly increase continuously between rhythms III and V.

TABLE 2. APATITE-PLAGIOCLASE DISTRIBUTION COEFFICIENTS

\begin{tabular}{|c|c|c|c|c|c|}
\hline \multirow[b]{2}{*}{$D^{\text {apat-plag }}$} & \multicolumn{3}{|c|}{ Rhythms } & \multirow[b]{2}{*}{$s$} & \multirow[b]{2}{*}{ Average } \\
\hline & III & IV & $\mathrm{V}$ & & \\
\hline $\mathrm{La}$ & 77 & 75 & 92 & 7.3 & 81 \\
\hline $\mathrm{Ce}$ & 127 & 126 & 154 & 9.3 & 136 \\
\hline $\mathrm{Sm}$ & 570 & 430 & 570 & 56 & 523 \\
\hline $\mathrm{Yb}$ & 560 & 480 & 630 & 82 & 557 \\
\hline
\end{tabular}

$s=$ pooled standard deviation.

4. The distribution coefficients of $\mathrm{La}, \mathrm{Ce}, \mathrm{Sm}$ and $\mathrm{Yb}$ between apatite and plagioclase ( $\mathrm{D}^{\text {apat-plag }}$ ) were calculated for each rhythm and are listed in Table 2. For a given element, the different values vary somewhat between the three rhythms but the differences are not statistically significant as can be shown by using a $t$-test of comparison. The $\mathrm{D}^{\text {apat-plag }}$ can thus be considered constant and averaged. This constancy which expresses the simultaneous increase of the REE* in both minerals could be assigned, not to differentiation, but to a proportional increase of the two sets of mineral-magma partition coefficients $\mathrm{D}_{\mathrm{REE}^{*}}^{\text {apat }}$ and $\mathrm{D}_{\mathrm{REE}^{*}}^{\mathrm{plag}}$. This explanation can be rejected. Indeed, the strikingly differing abundances and distribution patterns in the two minerals reflect major differences in cristallochemical control of the REE contents by those minerals. Variation in a mineral would very unlikely lead to a proportional variation in the other. We infer from this that the constancy of the apatite-plagioclase partition coefficient $\mathrm{D}^{\text {apat-plag }}$ is due to the constancy of the mineral-magma partition coefficients $\mathrm{D}^{\text {apat }}$ and $\mathrm{D}^{\mathrm{plag}}$. It should be noted that the major chemical compositions of the minerals vary little (from $\mathrm{An}_{45}$ to $\mathrm{An}_{37}$ ) or not at all (apatite). We can conclude that the REE enrichment between rhythms III and V both in apatite and plagioclase is due to the increase of these elements in the magma during the crystallization of the massif. The enrichment factor of the REE* in the magma between III and V is thus equal to those which were calculated for apatite and plagioclase here above and approaches 2 . These considerations also imply that the two minerals remained in equilibrium with the magma during crystallization of the cumulate. In other words, the rock minerals have formed through a process of adcumulus growth (Wager and Brown, 1968) in open system with the overlying magma.

On the other hand, it has been demonstrated (Duchesne,1971, 1978) that the differentiation process in the massif follows the Rayleigh Law (Neumann et al., 1954)

$$
c_{i, \rho}=c_{i, 0} F_{\rho} \bar{D}^{-1}
$$

where $c_{i, o}$ and $\mathrm{c}_{i, \rho}$ are the concentrations of a given trace element $i$ in the parental magma and in the residual

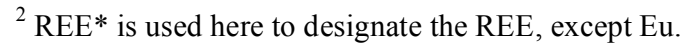


one at stage $p$ respectively, $F \rho$ is the weight fraction of magma remaining at stage $\rho$ and $\overline{\mathrm{D}}_{i}$ is the bulk (or effective) mineral-magma distribution coefficient

$\bar{D}_{i}=\sum_{j} \mu_{j} D_{i}^{j}$

where $\mu_{\mathrm{j}}$ is the weight fraction of a given mineral $j$ and $\mathrm{D}_{i}^{j}$ the distribution coefficient of the element $i$ between mineral $j$ and the magma $\left(\mathrm{D}_{\mathrm{i}}^{\mathrm{j}}=\mathrm{c}_{\mathrm{i}}^{\mathrm{j}} / \mathrm{c}_{\mathrm{i}}\right)$.

As shown by Anderson and Greenland (1969) if $\overline{\mathrm{D}}_{i}$ is negligible relatively to 1, equation (1) becomes

$$
c_{i, \rho}=\frac{c_{i, \mathrm{o}}}{F_{\rho}}
$$

and $c_{\mathrm{i}, \rho}$ is inversely proportional to $F_{\rho}$

The elements showing this property have been called hygromagmatophile by Treuil (Treuil and Varet, 1973; Treuil and Joron, 1975) who has demonstrated that a hygromagmatophile behaviour still holds within a few percent for $\overline{\mathrm{D}}$ values up to 0.2 .

Modelling of the Sr-Ca and K-Rb behaviours in the Bk-Sg differentiation (Duchesne, 1978) shows that the beginning of crystallization of apatite as a cumulate mineral (i.e. in the upper part of rhythm III) corresponds to $F_{I I I}=0.47$ and that the end of rhythm $\mathrm{V}$ is characterized by value of $\mathrm{F}_{\mathrm{V}}=0.21$. The ratio of concentrations of a hygromagmatophile element in the liquid (or in the minerals in equilibrium with the liquid) at stages III and V, i.e. $c_{i, V} / c_{i, I I I}$ is equal to $\mathrm{F}_{\mathrm{III}} / \mathrm{F}_{\mathrm{v}}$, that is 2.2 .

Since there is a close agreement between this value and the enrichment factors based on the apatite-plagioclase evolution the REE* behaviour between III and V is hygromagmatophile and consequently the $\overline{\mathrm{D}}_{\mathrm{REE}}{ }^{*}$ are $\leq 0.2$.

The average normative composition of the apatite-bearing rocks indicates an apatite content of $4 \%\left(\mu_{\text {apat }}\right)$ (Duchesne, 1978) and application of equation (2), in which the most important contribution to the $\overline{\mathrm{D}}_{i}$ is $\mu_{\text {apat }}$

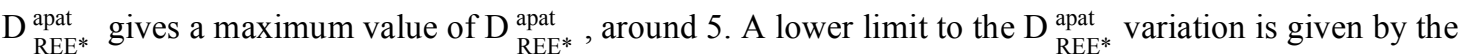

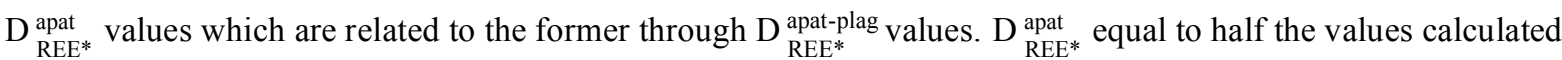
by Paster et al. (1974) for the Skaergaard have been adopted here (Table 3); they are distributed around 5 and lead to acceptable $\mathrm{D}_{\mathrm{REE}^{*}}^{\mathrm{apat}}$ values though somewhat lower than those reported by Paster et al. (1974).

The values obtained permit us to calculate the REE* contents in the residual magmas corresponding to rhythms III, IV and V, and application of equation (3) leads to the REE* contents in the parental magma (Fig. 1). It should be noted that equation (3) can be strictly applied between the base of the massif and the top of III, because, since apatite is absent from the association of the cumulate minerals, the $\overline{\mathrm{D}}_{\mathrm{REE}}$ are very low and the REE* behaviour is strongly hygromagmatophile.

TABLE 3. REE* DistribUtion COEFFICIENTS FOR APATITE AND PLAGIOCLASE

\begin{tabular}{lllllllllll}
\hline & $\mathrm{La}$ & $\mathrm{Ce}$ & $\mathrm{Nd}$ & $\mathrm{Sm}$ & $\mathrm{Eu} *$ & $\mathrm{Gd}$ & $\mathrm{Tb}$ & $\mathrm{Ho}$ & $\mathrm{Yb}$ & $\mathrm{Lu}$ \\
\hline $\mathrm{D}^{\text {apat }}$ & 4.3 & 5.5 & 6.9 & 7.3 & $(7.5)$ & 7.9 & 7.7 & 6.6 & 4.0 & $(3.25)$ \\
$\mathrm{D}^{\text {apat-plag }}$ & 81 & 136 & & 523 & & & & & 557 & \\
$\mathrm{D}^{\text {plag }}$ & .053 & .040 & $(.022)$ & .014 & $(.013)$ & $(.011)$ & $(.010)$ & $(.009)$ & .007 & $(.0065)$
\end{tabular}

Eu* is obtained by linear interpolation between Sm and Gd.

Values in brackets are obtained by interpolation after smoothing the distribution coefficient-atomic number curves. 
Europium cannot be considered hygromagmatophile. The rocks are rich in plagioclase and the high Eu anomaly in plagioclase gives high $\mathrm{D}_{\mathrm{Eu}}^{\mathrm{plag}}$ and $\overline{\mathrm{D}}_{\mathrm{Eu}}$ values. Furthermore, contrary to the $\mathrm{REE} \mathrm{E}^{*}, \mathrm{D}_{\mathrm{Eu}}^{\mathrm{plag}}$ varies with the An content of the plagioclase, with the oxygen fugacity of the magma (Philpotts and Schnetzler, 1972; Philpotts, 1970; Weill and Drake, 1973; Drake, 1975) and also with the composition of the magma (Morris et al., 1974). The first two factors must be taken into account in the Bk-Sg massif: the An content of plagioclase decreases from 50 to 37 from the beginning of the evolution to the upper part of V (Duchesne, 1978) and the appropriate use of the Buddington and Lindsley geothermo-barometer (Duchesne, 1972a) has shown that the $f_{02}-T$ conditions were $10^{-11 \pm 1} \mathrm{~atm}$ and $900-975^{\circ} \mathrm{C}$ as soon as magnetite appears in the sequence of rocks (in the middle of rhythm III) and that $f_{02}$ decreases with $T$ further on. The effects of composition of the magma are more difficult to assess. Morris et a/. (1974) could detect them experimentally with synthetic liquids of extreme compositions but with natural magmas no dependance could be observed. It is therefore assumed here that, within the range of composition of the successive liquids, the influence of this factor is negligible in regard to that of the first two factors.

The available data for Bk-Sg allow us to calculate the $\mathrm{D}_{\mathrm{Eu}}^{\text {plag }}$ variations. The following equations give the evolution of the Eu anomaly in the magmatic liquids between the initial stage (0) and rhythm III (eq. 4) and between rhythms III and V (eq. 5).

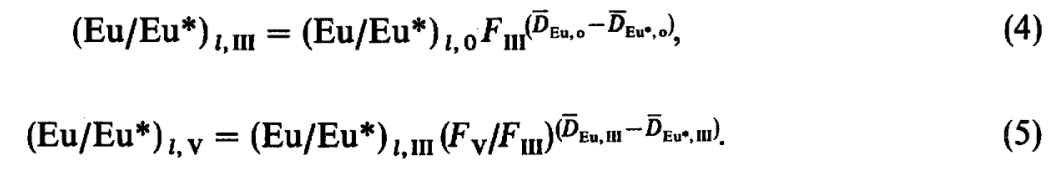

The equilibrium between plagioclase, apatite and magmatic liquids in stages III and $\mathrm{V}$ is expressed by equations (6) and (7):

$$
\begin{aligned}
& D_{\mathrm{Eu}, \mathrm{III}}^{\text {plag }}=\frac{E u_{\text {plag, III }}}{E u_{\text {apat, III }}} D_{\mathrm{Eu}, \mathrm{III}}^{\mathrm{apa}}, \\
& D_{\mathrm{Eu}, \mathrm{v}}^{\text {plag }}=\frac{E u_{\text {plag, }}}{E u_{\text {apat }, \mathrm{v}}} D_{\mathrm{Eu}, \mathrm{v} .}^{\text {apat }}
\end{aligned}
$$

Since $\mathrm{D}_{\mathrm{Eu}} \cong \mathrm{D}_{\mathrm{Eu}} *$ in minerals other than plagioclase and $\mathrm{D}_{\mathrm{Eu}^{*}}^{\text {plag }}$ is negligible compared to

$\mathrm{D}_{\mathrm{Eu}}^{\text {plag }} u, \overline{\mathrm{D}}_{\mathrm{Eu}}-\overline{\mathrm{D}}_{\mathrm{Eu}} * \mu_{\mathrm{plag}} \mathrm{D}_{\mathrm{Eu}}^{\mathrm{plag}}$. In the present case, as indicated above, $\mu_{\text {plag }}$ is equal to 0.74 and 0.45 for rhythms III and $\mathrm{V}$, respectively. $\mathrm{F}_{\mathrm{III}}$ and $\mathrm{F}_{\mathrm{V}}$ are equal to 0.47 and 0.21 , respectively.

In order to solve equations (4) to (7) the following hypotheses can be introduced:

1. $\left(\mathrm{Eu} / \mathrm{Eu}^{*}\right)_{0}=1$, i.e. the initial magma has no Eu anomaly, as is the case in the Hidra massif (Duchesne et al., 1974).

2. $\mathrm{D}_{\mathrm{Eu}, \mathrm{III}}^{\mathrm{apat}}=\mathrm{D}_{\mathrm{Eu}, \mathrm{V}}^{\mathrm{apat}}=$ constant. It has already been shown that $\mathrm{D}_{\mathrm{REE}^{*}}^{\text {apat }}$ is constant. Since $\mathrm{Eu}^{3+}$ is mainly incorporated by apatite (more than $95 \%$ of the total Eu using the method of calculation of Philpotts, 1970), the variations of the $\mathrm{Eu}^{2+} / \mathrm{Eu}^{3+}$ ratio in the magma are not likely to be recorded by apatite.

Resolution of the system gives the values of the four unknowns:

$\mathrm{D}_{\mathrm{Eu}, 0}^{\text {plag }}=0.51, \mathrm{D}_{\mathrm{Eu}, \mathrm{III}}^{\mathrm{plag}}=0.45, \mathrm{D}_{\mathrm{Eu}, \mathrm{V}}^{\mathrm{plag}}=0.75$ and $\mathrm{D}_{\mathrm{Eu}}^{\mathrm{apat}}{ }_{u}=6.95$.

Evaluation of the oxygen fugacity can be obtained by applying the experimental relation of Drake (1975):

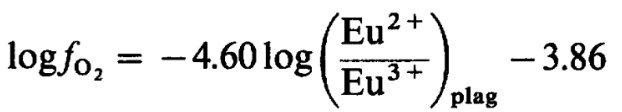


in which $\mathrm{Eu}^{3+}$ is calculated by

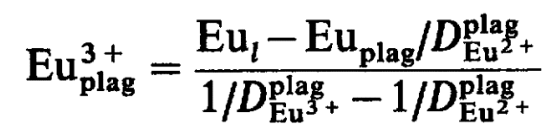

where, according to Philpotts (1970), $\mathrm{D}_{\mathrm{Eu}^{2+}}^{\mathrm{plag}}=\mathrm{D}_{\mathrm{Sr}}^{\mathrm{plag}}$. The $\mathrm{D}_{\mathrm{Sr}}^{\mathrm{plag}}$ values obtained by quantitative modelling of the Sr-Ca evolution (Duchesne, 1978), i.e. 2.0, 2.3 and 2.7 for stages 0, III and V respectively, were introduced in the equations to calculate the $f_{O 2}$ values at the different stages (see Table 4 , line 1).

The results obtained are semi-quantitative. Drake's geobarometer leads in the present case to $f_{\mathrm{O} 2}$ values differing by two orders of magnitude if the $\mathrm{Eu}^{2+} / \mathrm{Eu}^{3+}$ ratio of the liquid is used instead of that of the plagioclase. It should, however, be noted that where the oxide mineral assemblage permits calculating $f_{\mathrm{O} 2}$ (i.e. in rhythm III), the value obtained $\left(10^{-11} \mathrm{~atm}\right)$ is similar to that based on $\mathrm{Eu}$ in plagioclase. There is also a good agreement in the fact that the $f_{\mathrm{O} 2}$ calculated by the two methods decrease from rhythm III to rhythm $\mathrm{V}$, a normal trend for fractional crystallization in a closed system (Osborn, 1959).

The calculation, however, gives unexpected results for the initial stage (stage 0): $\mathrm{D}_{\mathrm{Eu}, 0}^{\text {plag }}$ is higher than $\mathrm{D}_{\mathrm{Eu}, \mathrm{III}}^{\mathrm{plag}}$ and $f_{\mathrm{O} 2}$ is lower than at stage III, which gives an evolution reversed to the trends found in the rest of the sequence. The $f_{\mathrm{O} 2}$ at stage 0 cannot be calculated by means of the association of the oxides because magnetite is absent up to rhythm III. It is thus not possible to confirm the trend between 0 and III by an independent method. In fact, this anomaly could be due to a lack of precise evaluation of the factor $F_{v}$ introduced in equation (5) and could have no geochemical and petrological meanings. The method used to determine factor $F_{v}$ (Duchesne, 1978) indeed permits a small interval of variation about the value 0.21 . If a small decrease of $F_{v}-$ from, say, 0.21 to 0.20 - is admitted, a new set of values can be calculated (Table 4, line 2) for the $\mathrm{D}_{\mathrm{Eu}}^{\mathrm{plag}}$ and $\mathrm{D}_{\mathrm{Eu}}^{\text {apat }}$ partition coefficients as well as for the $f_{\mathrm{O} 2}$. It is observed that the major effect of the decrease is to modify the values at stage 0 without much change at stages III and V. By decreasing sufficiently $\mathrm{F}_{\mathrm{v}}$, it is thus possible to increase $f_{O 2}$ values at stage 0 in order to obtain a set of continuously decreasing $f_{\mathrm{O} 2}$ values, i.e. a normal $f_{\mathrm{O} 2}$ evolution throughout the whole sequence (Table 4, lines 3 and 4). The set of values with $\mathrm{F}_{\mathrm{v}}=0.186$ and $\mathrm{D}_{\mathrm{Eu}}^{\text {apat }}=5.80$ is eventually preferred because it gives $f_{\mathrm{O} 2}$ conditions at the base of the massif close to those of the $\mathrm{Ni}-\mathrm{Ni} 0$ buffer, assuming an intrusion temperature of $1000-1100^{\circ} \mathrm{C}$.

\section{The Iron-Titanium Oxide Ore-bodies}

The Fe-Ti oxide ore-bodies studied here stake out the northern limit of the Håland massif (S. Egersund). They constitute small discordant lenticular masses or veins either within the Håland massif (Hesnes, Eigeröy, Rödemyr II) or at the limit with a complex unit called by Michot (1955) the norito-granitic zone (Kydlandsvatn, Kaknuden). A magmatic origin is unquestionable for the first ones but a metasomatic origin has been put forward for the last ones by Michot (1956). Field relationships are, however, ambiguous and available geochemical data (Duchesne, 1973) have already shown the great similarities between these ore-bodies and magmatic ones. The following data will also plead in favour of a similar origin.

The situation and description of the ore-bodies have been given by Hubaux (1960) and Duchesne (1973) ${ }^{3}$. In Kydlandsvatn, the association of the oxides is hemo-ilmenite + homogeneous Ti-poor magnetite (Type II of Duchesne, 1973). In the other bodies a homogeneous ilmenite coexists with Ti-magnetite (type III). In the former, apatite-bearing ores are an exception and the amount of apatite is approximately 20 vol. $\%$. In the latter, apatite is always present (nelsonite) and in Hesnes and Eigeröy its content approaches 30-35 vol.\%, a possible eutectical composition according to Philpotts (1967). A deuteric readjustment of the chemical composition of the oxides has taken place in all ore-bodies down to $\mathrm{T}-f_{\mathrm{O} 2}$ conditions indicated by the Buddington and Lindsley geothermo-barometer (Table 4).

Trace elements in magnetite and ilmenite (Duchesne, 1973 and Table 5) show large variations. Ore-bodies with Ti-rich magnetite (i.e. Hesnes and Eigeröy) have V, Cr, Ni, Co contents lower and a Zn content higher than those with Ti-poor magnetite. Similar trends have been observed in the Bk-Sg oxides from the bottom to the top of the

\footnotetext{
${ }^{3}$ Except for Rödemyr II which is situated within the Håland massif and thus distinct by its geological situation and mineral paragenesis from the Rödemyr Mine mentioned by these authors.
} 
massif (Duchesne, 1972a), which justifies the use of trace elements in the oxides as a semi-quantitative differentiation index.

\section{REE in Apatites}

The results for apatites in the ore-bodies are included in Table 1 and plotted on Fig. 2. If Nd is excepted for the same reasons as those already developed, the REE* show very regular patterns with nearly constant La/Yb ratios. The similarities between Hesnes and Eigeröy as well as between Kaknuden and Rödemyr II are striking. In the latter case it considerably strengthens the hypothesis of a common origin of the two occurrences. The Eu anomaly increases with the REE content. This evolution is similar to what can be anticipated by means of the differentiation index based on the oxides (Table 5) and also to the Bk-Sg trend. The consistency between trace element behaviour in the oxides and the REE in apatites thus suggests that fractional crystallization, in which plagioclase plays an important role, is a possible mechanism for the generation of the ore-bodies. Segregation of Fe, Ti-rich liquids (filter-press) has taken place at successive stages of the magmatic differentiation of the parental magma of the anorthosite series. This is consistent with the hypothesis already put forward by Duchesne (1973).

The REE content of the liquids in equilibrium with apatites of Kydlandsvatn, Kaknuden-Rödemyr II and Eigeröy-Hesnes (Fig. 2) has been calculated using $D_{\text {REE }}{ }^{*}$ values of Table 3. Small negative Eu anomalies appear in the Kydlandsvatn liquid if $\mathrm{D}_{\mathrm{Eu}}^{\text {apat }}$ values within the range 6.95 and 5.80, taken from Table 4, are used. They can be explained using a similar equation to (4) and the proper $\mathrm{D}_{\mathrm{Eu}}^{\mathrm{plag}}$ values, by crystallization from the initial stage to $F$ values between 0.58 and 0.74 of a hypothetical plagioclase-rich cumulate $\left(\mu_{\text {plag }}=0.80\right)$ now represented by the anorthositic massifs. The extreme values for the REE in the initial liquid are plotted on Fig. 2. $F$ values for the Hesnes-Eigeröy liquid vary between 0.18 and 0.24 and for Kaknuden-Rödemyr II, between 0.49 and 0.62 .

During this first interval of crystallization, a hemo-ilmenite-rich liquid could be segregated and formed orebodies of Type I (hemo-ilmenite without magnetite) (Duchesne, 1973). It is to be recalled that occurrence of hemo-ilmenite as the only oxide is also characteristic of the beginning stage of the Bk-Sg crystallization. 
Published in : Origin and distribution of the elements (1979), pp. 199-212

Status : Postprint (Author's version)

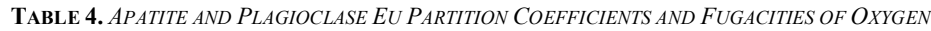

\begin{tabular}{|c|c|c|c|c|c|c|c|c|c|c|c|c|c|}
\hline \multirow[b]{2}{*}{$F_{\mathrm{v}}$} & \multirow[b]{2}{*}{$D_{\mathrm{Eu}}^{\text {apat }}$} & \multirow[b]{2}{*}{$D_{\mathrm{Eu}}^{\text {plag }}$} & \multicolumn{2}{|c|}{ Initial Stage $\mathrm{O}$} & \multirow[b]{2}{*}{$-\log f_{0 / 2}$} & \multirow[b]{2}{*}{$D_{\mathrm{Eu}}^{\text {plag }}$} & \multicolumn{2}{|c|}{ Stage III } & \multirow[b]{2}{*}{$-\log f_{0 / 2}$} & \multirow[b]{2}{*}{$D_{\mathrm{Eu}}^{\text {plag }}$} & \multicolumn{2}{|c|}{ Stage V } & \multirow[b]{2}{*}{$-\log f_{0 / 2}$} \\
\hline & & & $\left(\frac{\mathrm{Eu}^{2+}}{\mathrm{Eu}^{3+}}\right)_{\text {plag }}$ & $\left(\frac{\mathrm{Eu}^{3+}}{\mathrm{Eu}}\right)_{t}$ & & & $\left(\frac{\mathrm{Eu}^{2+}}{\mathrm{Eu}^{3+}}\right)_{\text {plag }}$ & $\left(\frac{\mathrm{Eu}^{3+}}{\mathrm{Eu}}\right)_{t}$ & & & $\left(\frac{E u^{2+}}{E u^{3+}}\right)_{\text {plag }}$ & $\left(\frac{\mathrm{Eu}^{3+}}{\mathrm{Eu}}\right)_{l}$ & \\
\hline 0.21 & 6.95 & 0.57 & 60 & 0.72 & 12.1 & 0.45 & 42 & 0.80 & 11.3 & 0.75 & 79 & 0.72 & 12.6 \\
\hline $0.20^{1}$ & 6.34 & 0.41 & 39 & 0.79 & 11.2 & 0.41 & 38 & 0.82 & 11.1 & 0.69 & 69 & 0.75 & 12.3 \\
\hline $0.19^{2}$ & 6.00 & 0.32 & 28 & 0.84 & 10.5 & 0.39 & 35 & 0.83 & 11.0 & 0.65 & 65 & 0.76 & 12.2 \\
\hline $0.18^{6}$ & 5.80 & 0.27 & 23 & 0.87 & 10.1 & 0.38 & 34 & 0.83 & 10.9 & 0.63 & 62 & 0.77 & 12.1 \\
\hline
\end{tabular}

TABLE 5. TRACE-ELEMENT CONTENTS (ppm) IN Fe-Ti OXIDE MINERALS *

\begin{tabular}{|c|c|c|c|c|c|c|c|c|c|}
\hline & \multicolumn{2}{|c|}{ Kydlandsvatn } & \multirow{2}{*}{$\begin{array}{l}\text { Rôdemyr II } \\
\mathrm{Mt}\end{array}$} & \multicolumn{2}{|c|}{ Kaknuden } & \multicolumn{2}{|c|}{ Eigeröy } & \multicolumn{2}{|c|}{ Hesnes } \\
\hline & $\mathrm{Ilm}$ & $\mathrm{Mt}$ & & $\mathrm{Ilm}$ & $\mathrm{Mt}$ & $\mathrm{Ilm}$ & $\mathrm{Mt}$ & $\mathrm{Ilm}$ & $\mathrm{Mt}$ \\
\hline $\mathrm{V}$ & 2500 & 6800 & 6800 & 400 & 7500 & 100 & 2600 & 130 & 2200 \\
\hline $\mathrm{Cr}$ & 280 & 4400 & 700 & - & 500 & - & 2000 & - & 70 \\
\hline $\mathrm{Zn}$ & - & 320 & 780 & - & 1400 & - & 3000 & - & 1400 \\
\hline $\mathrm{Ni}$ & 270 & 550 & 200 & - & 250 & - & 90 & - & 60 \\
\hline Co & 150 & 150 & 130 & 80 & 140 & 40 & 90 & 40 & 60 \\
\hline Hem or Usp $\ddagger$ & 21.0 & 3.2 & & 3.4 & 13.1 & 2.3 & 41.5 & 5.1 & 22.2 \\
\hline$T^{\circ} \mathrm{C} \S$ & \multicolumn{2}{|c|}{$500-550^{\circ}$} & & \multicolumn{2}{|c|}{$600^{\circ}$} & \multicolumn{2}{|c|}{$670^{\circ}$} & \multicolumn{2}{|c|}{$680^{\circ}$} \\
\hline$f_{\mathrm{O} 2}{ }^{(\mathrm{atm})} \S$ & \multicolumn{2}{|c|}{$?$} & & \multicolumn{2}{|c|}{$10^{-21}$} & \multicolumn{2}{|c|}{$10^{-20}$} & \multicolumn{2}{|c|}{$10^{-18}$} \\
\hline
\end{tabular}

* Data from Duchesne (1973) except Rodemyr II.

$\S T^{\circ}$ and $f_{02}$ calculated according to the Buddington and Lindsley geothermo-barometer, are the conditions of deuteric equilibrium.

$\S$ Not detected, i.e. less than $80 \mathrm{ppm} \mathrm{Zn}, 70 \mathrm{ppm} \mathrm{Cr}, 30 \mathrm{ppm} \mathrm{Ni}$ 
FIG. 2. Chondrite-normalized REE patterns in apatites from Fe-Ti oxide ore-bodies and in magmatic liquids 1,2, 3, corresponding to Kydlansvatn, Kaknuden-Rödemyr II and Hesnes-Eigeröy respectively. Two extreme values are indicated for Eu in the liquids assuming $\mathrm{D}_{\mathrm{Eu}}^{\text {apat }}$ equal to 6.95 or 5.80 (see Table 4). The same $\mathrm{D}_{\mathrm{Eu}}^{\text {apat }}$ and corresponding $\underset{\mathrm{Eu}}{\mathrm{plag}}$ values (Table 4) lead to a range of possible parental liquids (0) (vertically hatched).

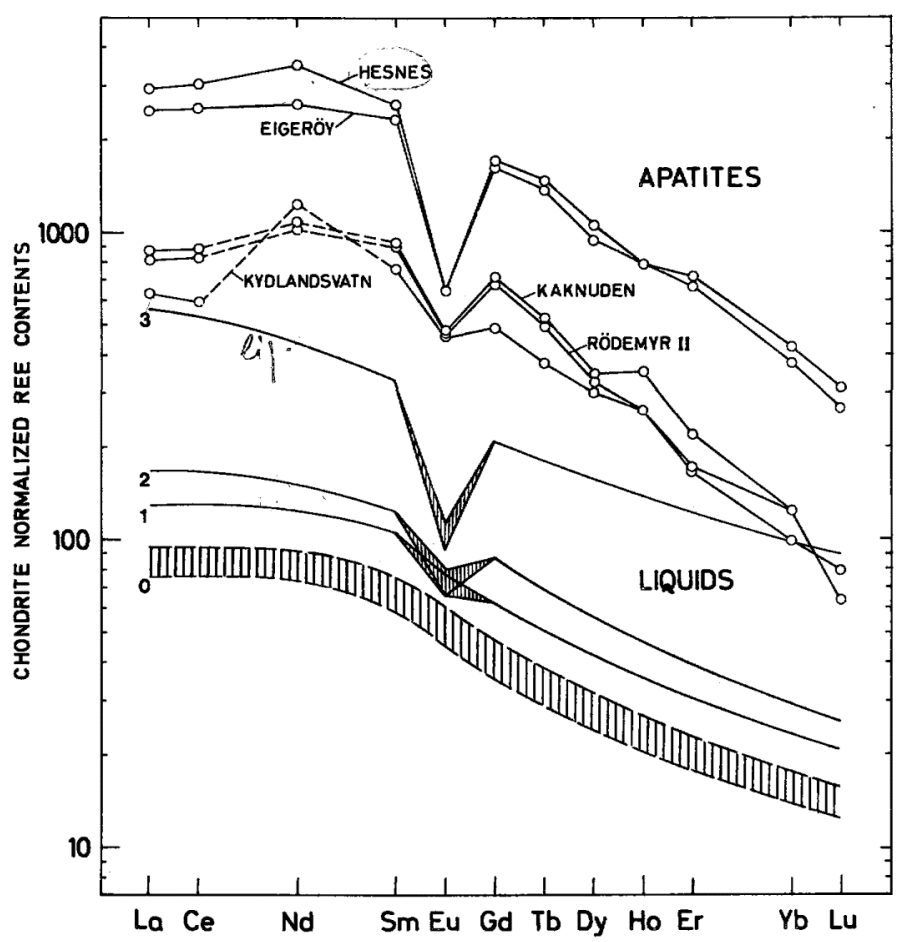

\section{Acknowledgements}

This paper has greatly benefited from an exhaustive review by D. M. Shaw. I. R. wishes to thank K. S. Heier, J. Dons and A. O. Brunfelt for providing laboratory facilities and helpful guidance during a period of work at the Mineralogical Geological Museum, University of Oslo. This research has been partly supported by the Belgian F.N.R.S.

\section{References}

ANDERSON, A. T. and GREenLAND, L. P. (1969) Phosphorous fractionation diagram as a quantitative indicator of crystallization differentiation of basaltic liquid. Geochim. Cosmochim. Acta, 33, 493-505.

BRUNFELT, A. O. and RoELANDTS, I. (1974) Determination of rare earths and thorium in apatites by thermal and epithermal neutronactivation analysis. Talanta, 21, 513-521.

DRAKE, M. J. (1975) The oxidation state of europium as an indicator of oxygen fugacity. Geochim. Cosmochim. Acta,39, 55-64.

DuCheSNE, J. C. (1971) Le rapport Sr/Ca dans les plagioclases du massif de Bjerkrem-Sogndal (Norvège méridionale) et son évolution dans la cristallisation fractionnée du magma plagioclasique. Chem. Geol. 8, 123-130.

DuChESNE, J. C. (1972a) Iron-titanium oxide minerals in the Bjerkrem-Sogndal massif, Southwestern Norway. J. Petrology, 13 , 57-81.

DuChesne, J. C. (1972b) Pyroxènes et olivines dans le massif de Bjerkrem-Sogndal (Norvège méridionale). Contribution à l'étude de la série anorthosite-mangérite. 24th Int. Geol. Congress, Montreal, sect 2, 320-328.

DUCHESNE, J. C. (1973) Les gisements d'oxydes de fer et titane dans les roches anorthositiques du Rogaland (Norvège méridionale). In: Les Roches plutoniques dans leurs rapports avec les gtes minéraux, Coll. E. Raguin. Masson, Paris, 403 pp.

DuCHESNe, J. C. (1977) Quantitative modeling of Sr, Ca, Rb and K in the Bjerkrem-Sogndal layered lopolith (S.W. Norway). Contr. Miner. Petrol. 66, 175-184. 
Published in : Origin and distribution of the elements (1979), pp. 199-212

Status : Postprint (Author's version)

Duchesne, J. C, Roelandts, I., DemaIffe, D., Hertogen, J., GiJbels, R. and De Winter, J. (1974) Rare-earth data on monzonoritic rocks related to anorthosites and their bearing on the nature of the parental magma of the anorthositic suite. Earth Planet. Sci. Lett. 24, 325335 .

Hubaux, A. (1960) Les gisements de fer titane de la région d'Egersund, Norvège. N. Jb. Miner., Festband Ramdohr,94, 926-992.

Michot, P. (1955) Anorthosites et anorthosites. Acad. Roy. Belgique, Bull. Cl. Sci., série 5, 41, 275-294.

Мiснот, P. (1956) Les gisements de minerais noirs de la région d'Egersund Ann. Soc. Géol. Belgique, 79,183-202.

Michot, P. (1960) La géologie de la catazone: Le problème des anorthosites, la palingenèse basique et la tectonique catazonale dans le Rogaland méridional (Norvège méridionale). Norges Geol. Unders. 212g, 1-54.

MichOT, P. (1965) Le magma plagioclasique. Geol. Runds. 54, 956-976.

Morris, R. V., HASKin, L. A., Biggar, G. M. and O'HARA, M. J. (1974) Measurement of the effects of temperature and partial pressure of oxygen on the oxidation states of europium in silicate glasses. Geochim. Cosmochim. Acta, 38, 1447-1459.

NAGASAWA, H. (1970) Rare-earth concentrations in zircons and apatites and their host dacites and granites. Earth Planet. Sci. Lett. 9, 359364.

Neumann, H., Mead, J. and Vitaliano, C. J. (1954) Trace element variation during fractional crystallization as calculated from the distribution law. Geochim. Cosmochim. Acta, 6, 90-99.

OSBORN, E. F. (1959) Role of oxygen pressure in the crystallization and differentiation of basaltic magma. Am. J. Sci. 257, 609-647.

PASTER, T. P., SCHAUWECKER, D. S. and HASKIN, L. A. (1974) The behaviour of some trace elements during solidification of the Skaergaard layered series. Geochim. Cosmochim. Acta, 38, 1549-1577.

PhILPOTTS, A. R. (1967) Origin of certain iron-titanium oxide and apatite rocks. Econ.Geol. 62, 303-315.

PhILPOTTS, J. A. (1970) Redox estimation from a calculation of $\mathrm{Eu}^{2+}$ and $\mathrm{Eu}^{3+}$ concentrations in natural phases. Earth Planet. Sci. Lett. 9 , $257-268$

Philpotts, J. A. and Schnetzler, C. C. (1970) Phenocryst-matrix partition coefficients for K, Rb, Sr and Ba, with applications to anorthosite and basalt genesis. Geochim. Cosmochim. Acta, 34, 307-322.

Philpotts, J. A. and Schnetzler, C. C. (1972) Large trace cation partitioning in igneous processes. 24th Int. Geol. Congress, Montreal, sect. $10,51-59$

Puchelt, H. and EMmerman, R. (1976) Bearing of rare earth patterns of apatites from igneous and metamorphic rocks. Earth Planet. Sci. Lett. 31, 279-286.

RoElANDTS, I. (1975) Contribution au dosage par activation neutronique des terres rares et d'autres éléments en trace dans les roches magmatiques. Doctorat thesis, University of Liège (unpublished).

Sun, SHEN-Su and HAnson, G. N. (1976) Rare earth element evidence for differentiation of McMurdo Volcanics, Ross Island, Antarctica. Contr. Miner. Petrol. 54, 139-155.

TREUIL, M. and JORON, J. L. (1975) Utilisation des éléments hygro magmatophiles pour la simplification de la modélisation quantitative des processus magmatiques. Exemples de l'Afar et de la dorsale médioatlantique. Soc. Ital. Mineral, e Petrol., Milano, 31, (1), $125-174$.

TREuIL, M. and VARET, J. (1973) Critères volcanologiques, pétrologiques et géochimiques de la genèse et de la différenciation des magmas basaltiques: exemple de l'Afar. Bull. Soc. Géol. France, $7^{\mathrm{e}}$ s., 15(5-6), 506-540.

WAGER, L. R. and Brown, G. M. (1968) Layered Igneous Rocks. Oliver and Boyd Ltd., London, 588 pp.

WEILL, D..F. and DRAKE, M. J. (1973) Europium anomaly in plagioclase feldspar: experimental results and semi quantitative model. Science, $180,1059-1060$.

ZIELINSKI, R. and FREY, F. (1970) Gough Island: Evaluation of a fractional crystallization model. Contr, Miner. Petrol. 29, $242-254$. 